\title{
Supplementation of folic acid in pregnancy and the risk of preeclampsia and gestational hypertension: a meta-analysis
}

\author{
Cheng Liu ${ }^{1} \cdot$ Chongdong Liu ${ }^{1}(0)$ Qiushi Wang ${ }^{1} \cdot$ Zhenyu Zhang $^{1}$
}

Received: 8 January 2018 / Accepted: 13 June 2018 / Published online: 5 July 2018

(c) The Author(s) 2018

\begin{abstract}
Objectives We aimed to systematically assess the relationship between folic acid supplementation in pregnancy and risk of preeclampsia and gestational hypertension.

Methods The relevant studies were included by retrieving the Embase, PubMed and Cochrane library databases. Data extraction was conducted by two investigators independently. The risk ratio (RR) and $95 \%$ confidence interval (CI) were used as effect indexes to evaluate the relationship between folic acid supplementation and risk of gestational hypertension or preeclampsia. A subgroup analysis was performed according to the supplementation patterns of folic acid. The homogeneity of the effect size was tested across the studies, and publication biases were examined.

Results In total, 13 cohort studies and 1 randomized controlled trial study was included, containing 160,562 and 149,320 women with and without folic acid supplementation during pregnancy. Pooled results showed that risk of gestational hypertension was not associated with the supplementation of folic acid. However, folic acid supplementation during pregnancy could significantly reduce the risk of preeclampsia. Moreover, the results of subgroup analysis showed that the decreased preeclampsia risk was associated with supplementation of multivitamins containing folic acid rather than folic acid alone. Conclusions Our findings indicate that the supplementation of multivitamins containing folic acid during pregnancy could significantly lower preeclampsia risk.
\end{abstract}

Keywords Folic acid $\cdot$ Risk of preeclampsia $\cdot$ Risk of gestational hypertension $\cdot$ Meta-analysis

\section{Introduction}

Gestational hypertension and preeclampsia are common hypertensive disorders during pregnancy [1,2]. Preeclampsia is a devastating complication of pregnancy responsible for maternal mortality and morbidity [3, 4]. Mothers with preeclampsia during pregnancy may result in neurocognitive dysregulation and suboptimal infant development in offspring [5]. During pregnancy, hypertension is a risk factor for diabetes and cardiovascular disease in later life $[6,7]$.

Electronic supplementary material The online version of this article (https://doi.org/10.1007/s00404-018-4823-4) contains supplementary material, which is available to authorized users.

Zhenyu Zhang

zhenyuzhang2000@163.com

1 Department of Obstetrics and Gynecology, Beijing Chao-Yang Hospital, Capital Medical University, No. 8 North Road of Workers Stadium, Chaoyang District, Beijing 100020, China
Preeclampsia is always caused by impaired placental perfusion, nevertheless, but other risk factors for preeclampsia remain unclear [8].

Accumulating evidences have suggested that elevated levels of blood homocysteine are a cause of gestational hypertension and preeclampsia $[9,10]$. In addition, more and more studies confirm that folic acid supplementation can reduce blood homocysteine levels [11, 12]. Furthermore, the relationship between folic acid supplementation and preeclampsia risk has been investigated by several epidemiological studies, but their results are inconsistent. Some studies showed that the supplementation of folic acid is beneficial in decreasing the incidence of preeclampsia and gestational hypertension during pregnancy [13-15]. However, Li et al. demonstrated that there was no association between the occurrence of preeclampsia or gestational hypertension and the consumption of folic acid alone during early pregnancy [16].

In light of these inconsistent results, we conducted this meta-analysis to systematically analyze exploration of the 
relationship between folic acid supplementation in pregnancy and the risk of preeclampsia or gestational hypertension. This meta-analysis will provide significant clues for further clinical studies.

\section{Materials and methods}

\section{Search strategy}

All relevant published studies were retrieved by searching the databases of Embase (http://www.embase.com), PubMed (http://www.ncbi.nlm.nih.gov/pubmed), and Cochrane library (http://www.thecochranelibrary.com/view/0/index .html) updated to 21 Aug 2017 with the following keywords: pregnancy, folic acid, preeclampsia, and gestational hypertension. The search terms were: (folic acid) AND pregnancy AND \{[hypertension OR (gestational hypertension)] OR [pre-eclampsia OR preeclampsia]\}. Moreover, manual retrieval for hard copy literature review was also performed in this study for including more studies.

\section{Inclusion and exclusion criteria}

The inclusion criteria were: (1) the study population was pregnant women; (2) comparison group was folic acid supplementation versus folic acid absence; (3) outcome indicators included the risk of gestational hypertension or preeclampsia.

The exclusion criteria were: (1) review literature, conference abstracts, and comments; (2) the studies about the association between the levels of folic acid in serum and gestational hypertension or preeclampsia; (3) animal experiments; (4) gene polymorphism analysis; (5) pregnant women with other specific diseases.

\section{Data extraction and quality assessment}

Data extraction was conducted in all eligible studies by two investigators independently using a standardized protocol. The extracted characteristics included the name of the first author, study design, study period, publication year, demographic characteristics (such as gender and age) of study population, sample size, the supplementation patterns of folic acid, the period of folic acid use, and the incidence of preeclampsia and gestational hypertension After finishing the data extraction, the extraction table was exchanged for check, and the disagreements were settled by discussing. The quality assessments for randomized controlled trials (RCTs) and cohort study were then performed based on the Cochrane risk of bias tool [17] and Newcastle-Ottawa Scale (NOS) [18], respectively. NOS contained 9 points: $\geq 7,5-6$, and $<5$ were considered methodologically to be excellent, fair, and poor.

\section{Statistical analysis}

The risk ratio (RR) and 95\% confidence interval (CI) were applied as effect indexes to analyze the relationship between the supplementation of folic acid and risk of preeclampsia or gestational hypertension. The homogeneity of effect size across the studies was tested with Cochran $Q$ statistics and the $I^{2}$ statistics [19]. If $P<0.05$ and $I^{2}>50 \%$, the homogeneity was significant and the random effects model was then applied to pool results, otherwise, the fixed effects model was used [20]. Based on the supplementation patterns of folic acid (folic acid alone versus multivitamins containing folic acid), the subgroup and sensitivity analyses were carried out with Stata 13.0 (StataCorp, College Station, TX, USA). Publication biases were assessed by Egger's regression test.

\section{Results}

\section{Description of eligible studies}

The flow chart for selection of eligible studies is shown in Fig. 1. In total, 741 articles, including 299 in PubMed, 401 in Embase and 41 in Cochrane library, were retrieved. After

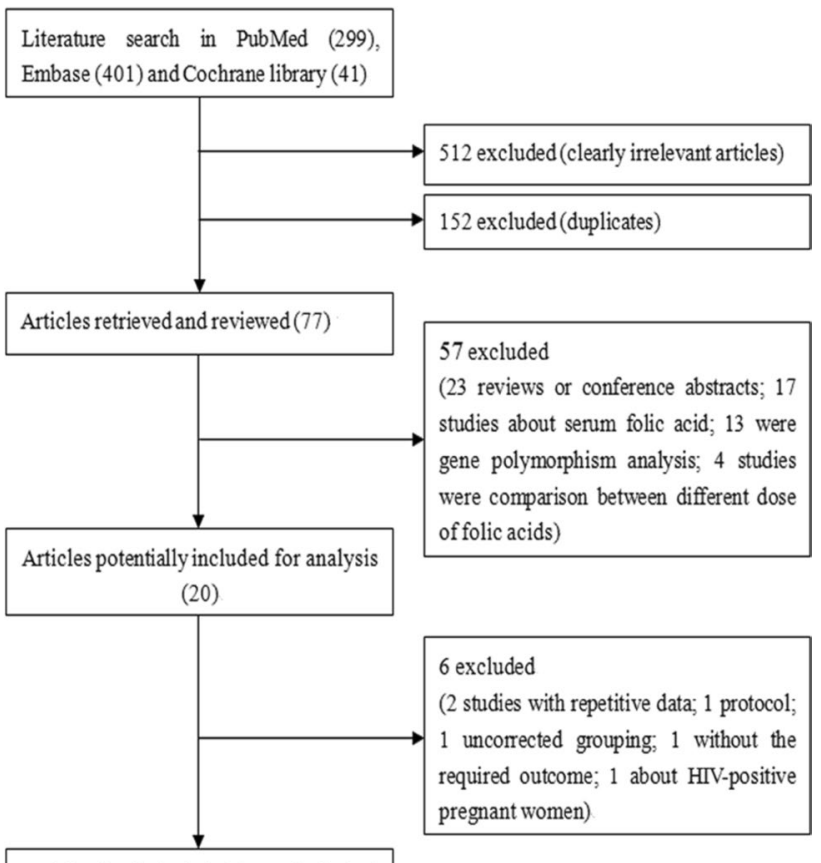

Articles finally included for analysis (14)

Fig. 1 Flowchart of the literature search and study selection 
reviewing the title, 152 duplicates and 512 clearly irrelevant articles were excluded. The remaining 77 articles were then selected by reviewing the abstract, and 57 studies were excluded according to our exclusion criteria, including 23 reviews or conference abstracts, 17 about serum folic acid, 13 gene polymorphism analysis, and 4 about comparison between different doses of folic acids. After further reviewing of the full text, six studies were excluded, including two with repetitive data, one protocol, one uncorrected grouping, one without the required outcome, and one about
HIV-positive pregnant women. At last, 14 eligible studies [13-16, 21-30] were included.

The characteristics of included studies are shown in Table 1. There were 13 cohort studies (12-14, 20-22, 24-30) and 1 RCT [24], containing 160,562 and 149,320 women with or without folic acid supplementation during pregnancy. The period in which the women received folic acid was presented: some was in preconception, some were in early second trimester, and some were throughout pregnancy. The included studies were conducted in China,

Table 1 The characteristics of included studies

\begin{tabular}{|c|c|c|c|c|c|c|c|c|}
\hline \multirow[t]{2}{*}{ Study } & \multirow[t]{2}{*}{ Study type } & \multirow[t]{2}{*}{ Country } & \multirow[t]{2}{*}{ Study period } & \multirow{2}{*}{$\begin{array}{l}\text { The period of folic } \\
\text { acid use }\end{array}$} & \multirow[t]{2}{*}{ Folic acid supplement } & \multicolumn{2}{|l|}{ No. } & \multirow{2}{*}{$\begin{array}{l}\text { Quality } \\
\text { assess- } \\
\text { ment }\end{array}$} \\
\hline & & & & & & Suppl. & No suppl. & \\
\hline Bodnar et al. [21] & PCS & USA & 1997-2001 & $\begin{array}{l}\text { In the past } 6 \text { months, } \\
\text { daily use }\end{array}$ & $\begin{array}{l}\text { Periconceptional } \\
\text { multivitamin use }\end{array}$ & 860 & 975 & 7 \\
\hline Bukowski et al. [22] & PCS & USA & 1999-2002 & $\begin{array}{l}\text { In the past } 1 \text { year, } \\
\text { daily use }\end{array}$ & $\begin{array}{l}\text { Preconceptional } \\
\text { folate supplementa- } \\
\text { tion }\end{array}$ & 12,444 & 15,259 & 7 \\
\hline \multirow[t]{2}{*}{ Catov et al. [23] } & \multirow[t]{2}{*}{ PCS } & \multirow[t]{2}{*}{ Denmark } & \multirow[t]{2}{*}{$1997-2003$} & \multirow{2}{*}{$\begin{array}{l}4 \text { weeks before the } \\
\text { LMP through } \\
8 \text { weeks after the } \\
\text { LMP }\end{array}$} & $\begin{array}{l}\text { Periconceptional } \\
\text { multivitamin use }\end{array}$ & 21,785 & 11,503 & \multirow[t]{3}{*}{6} \\
\hline & & & & & Folate-only users & 2609 & 11,503 & \\
\hline Charles et al. [24] & RCT & UK & 1966-1967 & $<37$ weeks gestation & $\begin{array}{l}\text { Periconceptional folic } \\
\text { acid use }\end{array}$ & 1902 & 917 & \\
\hline $\begin{array}{l}\text { Hernandez-Diaz et al. } \\
\text { [25] }\end{array}$ & RCS & USA, Canada & $1993-2000$ & $\begin{array}{l}\text { From } 2 \text { months before } \\
\text { conception through } \\
\text { the entire pregnancy }\end{array}$ & $\begin{array}{l}\text { Periconceptional folic } \\
\text { acid use }\end{array}$ & 1953 & 147 & 7 \\
\hline Kim et al. [26] & RCS & South Korea & 2009-2010 & NR & $\begin{array}{l}\text { Prenatal intake of } \\
\text { folic acid }\end{array}$ & 134 & 81 & 8 \\
\hline Li et al. $[16,31]$ & RCS & China & 1993-1996 & $\begin{array}{l}\text { During early preg- } \\
\text { nancy }\end{array}$ & $\begin{array}{l}\text { Folic acid supplemen- } \\
\text { tation }\end{array}$ & 92,731 & 100,823 & 9 \\
\hline Liu et al. [27] & PCS & China & 2010-2012 & $\begin{array}{l}\text { Pre- and post-con- } \\
\text { ception }\end{array}$ & Folic acid intake & 7864 & 2315 & 7 \\
\hline $\begin{array}{l}\text { Martinussen et al. } \\
\text { [28] }\end{array}$ & PCS & USA & 1996-2000 & First trimester overall & $\begin{array}{l}\text { Folic acid supple- } \\
\text { mentation in early } \\
\text { pregnancy }\end{array}$ & 3301 & 346 & 8 \\
\hline $\begin{array}{l}\text { Timmermans et al. } \\
\text { [29] }\end{array}$ & PCS & Netherlands & $2002-2006$ & Before 8 weeks & $\begin{array}{l}\text { Preconceptional } \\
\text { folate supplementa- } \\
\text { tion }\end{array}$ & 2362 & 1770 & 9 \\
\hline \multirow[t]{2}{*}{ Vanderlelie et al. [13] } & \multirow[t]{2}{*}{ PCS } & \multirow[t]{2}{*}{ Australia } & \multirow[t]{2}{*}{ 2006-2011 } & \multirow[t]{2}{*}{$\begin{array}{l}\text { The first trimester of } \\
\text { pregnancy }\end{array}$} & $\begin{array}{l}\text { First trimester multi- } \\
\text { vitamin/mineral use }\end{array}$ & 719 & 1066 & \multirow[t]{2}{*}{7} \\
\hline & & & & & Folate-only users & 476 & 1066 & \\
\hline Wang et al. [15] & PCS & China & 2010-2012 & $\begin{array}{l}\text { Before conception } \\
\text { and/or during preg- } \\
\text { nancy }\end{array}$ & $\begin{array}{l}\text { Dietary folate intake } \\
\text { before conception } \\
\text { and during preg- } \\
\text { nancy }\end{array}$ & 794 & 265 & 7 \\
\hline \multirow[t]{2}{*}{ Wen et al. [30] } & \multirow[t]{2}{*}{ PCS } & \multirow[t]{2}{*}{ Canada } & \multirow[t]{2}{*}{ 2002-2005 } & \multirow[t]{2}{*}{$\begin{array}{l}\text { In early second } \\
\text { trimester }\end{array}$} & $\begin{array}{l}\text { Prenatal multivitamin } \\
\text { use }\end{array}$ & 2317 & 238 & \multirow[t]{2}{*}{6} \\
\hline & & & & & Folate-only users & 421 & 238 & \\
\hline \multirow[t]{2}{*}{ Wen et al. [14] } & \multirow[t]{2}{*}{ PCS } & \multirow[t]{2}{*}{ Canada } & \multirow[t]{2}{*}{$2002-2008$} & \multirow[t]{2}{*}{$\begin{array}{l}\text { In early second } \\
\text { trimester }\end{array}$} & $\begin{array}{l}\text { Prenatal multivitamin } \\
\text { use }\end{array}$ & 7265 & 404 & \multirow[t]{2}{*}{6} \\
\hline & & & & & Folate-only users & 625 & 404 & \\
\hline
\end{tabular}

PCS prospective cohort study; $R C S$ retrospective cohort study; $R C T$ randomized controlled trail; Suppl supplementation; LMP last menstrual period 
United States, UK, Australia, Denmark, Canada, and South Korea. The NOS assessment showed that the quality of the included 13 cohort studies was excellent (6-9 points). Moreover, RCT conducted by Charles et al. [24] showed that blinding of participants and personnel, allocation concealment, blinding of outcome assessment, and incomplete outcome data were all at the low risk (supplementary Fig. 1).

\section{Relationship between supplementation of folic acid and risk of gestational hypertension}

Four studies [23, 25, 29, 31] about the relationship between folic acid supplementation and gestational hypertension risk were included in this meta-analysis. The heterogeneity was high across the above four studies $\left(I^{2}=89 \%, P<0.01\right)$. As shown in Fig. 2, there was no relationship between the supplementation of folic acid and gestational hypertension risk $(\mathrm{RR}=1.19,95 \%$ CI $0.92-1.54, P=0.19)$.

\section{Relationship between supplementation of folic acid and risk of preeclampsia}

Twelve studies [13-15, 21-24, 26, 27, 29-31] were included to explore the relationship between folic acid supplementation and preeclampsia risk. The heterogeneity was also high across these studies $\left(I^{2}=86 \%, P<0.01\right)$, and the pool results showed that the decreased risk of preeclampsia is related to folic acid supplementation during pregnancy $(\mathrm{RR}=0.69$, $95 \%$ CI $0.58-0.83, P<0.01$, Fig. 3 ).

Furthermore, according to the patterns of supplementation of folic acid, a subgroup analysis was performed. The results showed that the supplementation of multivitamins containing folic acid significantly decreased the risk of preeclampsia $(\mathrm{RR}=0.70,95 \% \mathrm{CI} 0.53-0.93, P=0.01)$, while the supplementation of folic acid alone had no significant effects on preeclampsia risk $(\mathrm{RR}=0.97,95 \% \mathrm{CI}$ $0.80-1.17, P=0.73$ ) (Fig. 4).

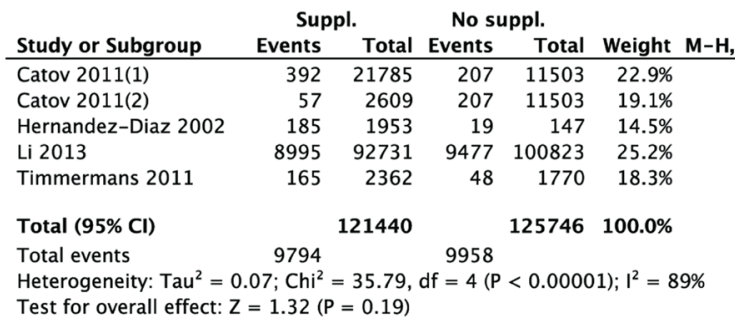

Risk Ratio Risk Ratio

M-H, Random, 95\% Cl

$1.00[0.85,1.18]$

$1.21[0.91,1.62]$

$0.73[0.47,1.14]$

$1.03[1.00,1.06]$

$2.58[1.88,3.53]$

$1.19[0.92,1.54]$ M-H, Random, 95\%

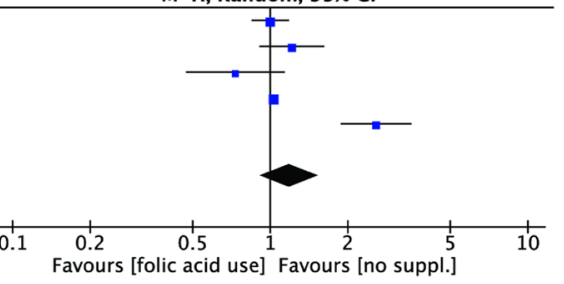

gestational hypertension. CI: confidence interval.

Fig. 2 Forest plot of the association between folic acid supplementation and risk of gestational hypertension. $C I$ confidence interval

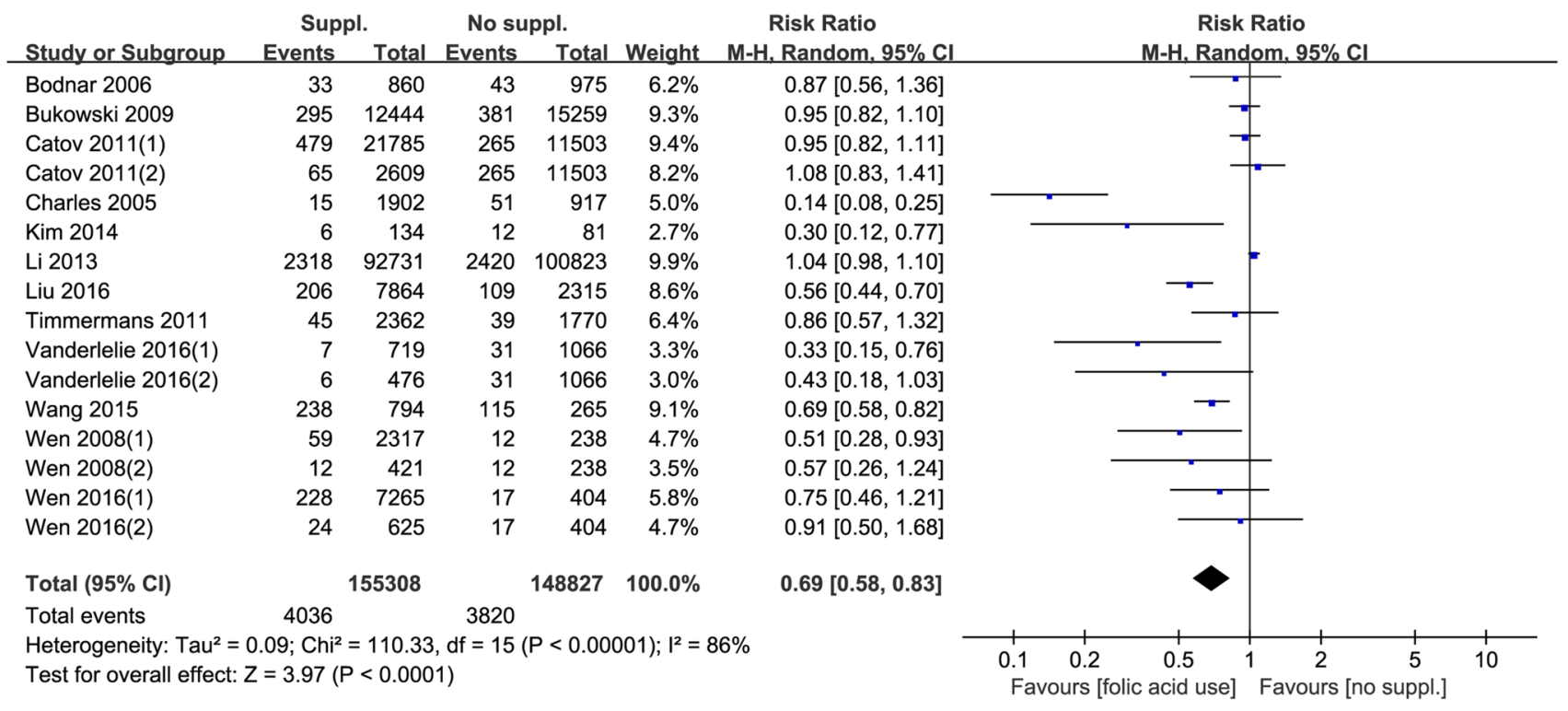

Fig. 3 Forest plot of the association between folic acid supplementation and risk of preeclampsia. $C I$ confidence interval 


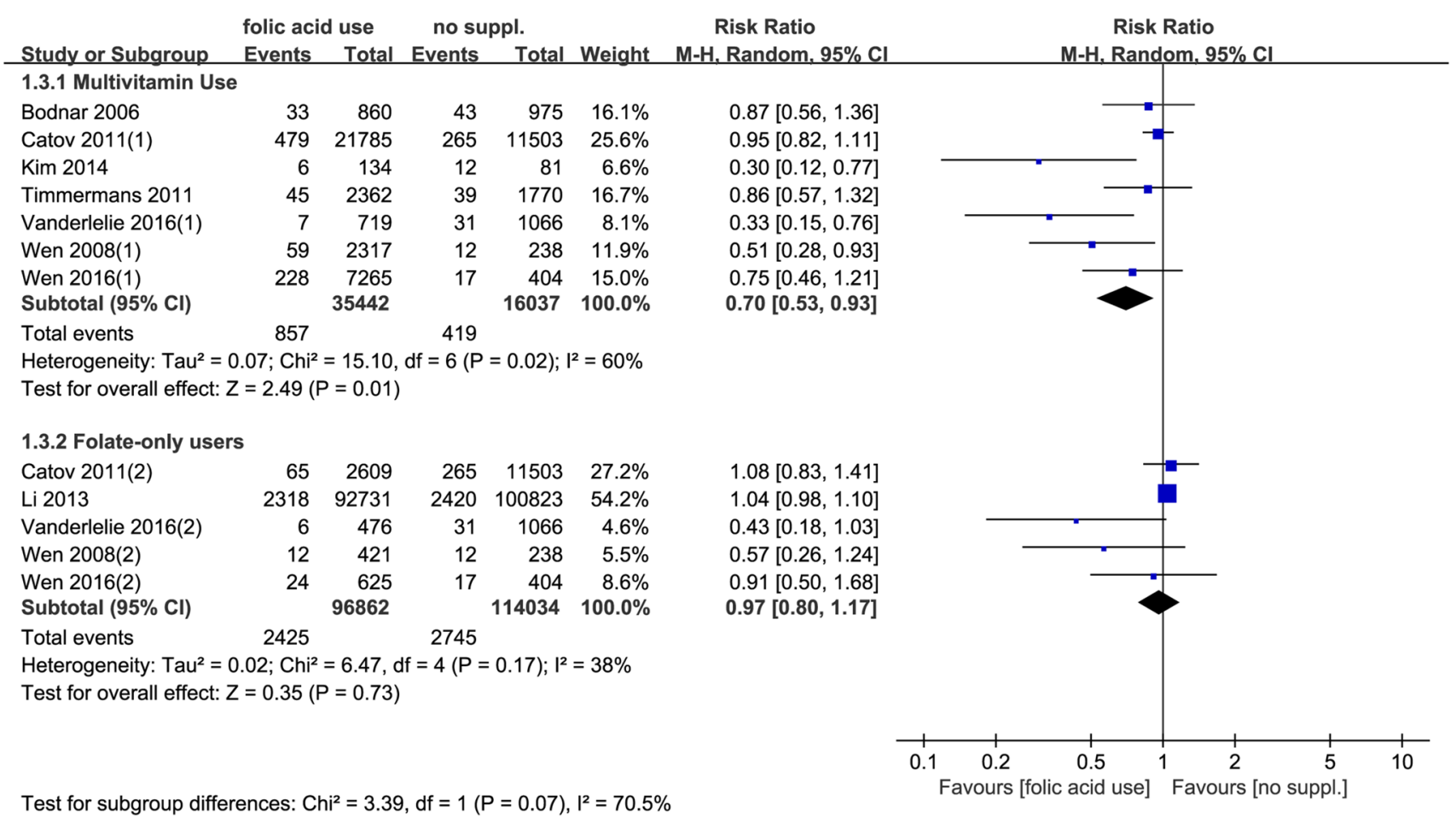

Fig. 4 Forest plot of the association between different patterns of folic acid supplementation and risk of preeclampsia. $C I$ confidence interval

\section{Publication bias}

The results of Egger's test showed that a significant publication bias existed among our included studies $(P=0.002)$. The publication bias was then verified using trim and fill method [32], and the obtained results were not changed. Moreover, a sensitivity analysis was performed by eliminating the included studies one by one, and eventually, the pooled results were also not significantly changed (Fig. 5).
Fig. 5 A sensitivity analysis for publication bias of the included studies. $C I$ confidence interval

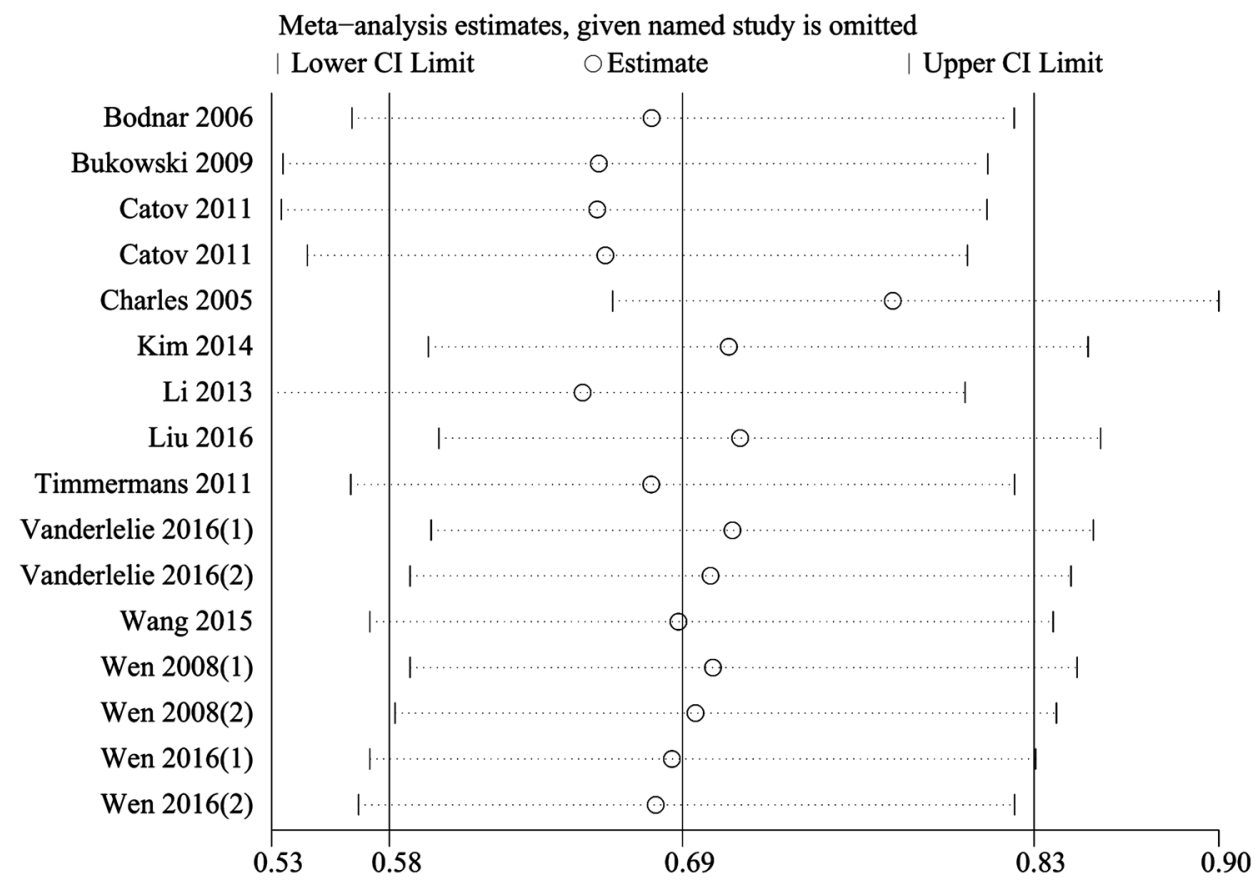




\section{Discussion}

In this meta-analysis, 14 studies were included and pooled results showed that the supplementation of folic acid during pregnancy significantly reduced preeclampsia risk, but had no effects on gestational hypertension risk. Moreover, the decreased preeclampsia risk was associated with supplementation of multivitamins containing folic acid rather than folic acid alone. These results merit further discussion.

Supplementation of folic acid has been found to decrease preeclampsia risk. The possibility is that folic acid can affect the levels of hyperhomocysteinemia, which is suggested to damage the vascular endothelium of the developing placenta [33]. Moreover, a folate deficiency may induce the apoptosis of human cytotrophoblast cells, thus possibly affecting trophoblast invasion and placental development $[34,35]$. Therefore, the supplementation of folic acid may improve placental implantation and subsequently affect the incidence of hypertensive pregnancy disorders. In this study, our results are consistent with the findings of a previous study reported by Catov et al. [36] that a decreased preeclampsia risk is related to multivitamin use, but there is no association between the risk of preeclampsia and folic acid supplement alone. Given the biologic rationale of folic acid in reducing the risk of developing preeclampsia, we speculate that folic acid may play a more important role in preeclampsia than other vitamins because the biologic mechanisms of other vitamins in reducing the risk of developing preeclampsia have not been fully explored. Moreover, previous RCTs have found that supplementation with vitamins $\mathrm{C}$ and $\mathrm{E}$ (without folic acid) during pregnancy has no protective effect on preeclampsia [37, 38]. Lv et al. also demonstrated that the risk for lower clinical pregnancy rate was not significantly correlated with deficient serum vitamin D level in infertile woman undergoing in vitro fertilization [39]. In addition to several studies that have confirmed a relationship between decreased preeclampsia risk and the supplementation of multivitamins containing folic acid [13, 14], we speculate that other vitamins may also play some roles in the prevention of preeclampsia, and the key roles of folic acid in preventing the risk of preeclampsia may be enhanced by other nutrients present in multivitamins. However, the ingredients of multivitamins in different included studies are largely unknown, hindering us to further explore the key other vitamins in preventing the risk of preeclampsia. More studies are still needed to confirm our observation.

Furthermore, strengths and limitations should be considered. Strengths of our study were that a total of
14 articles containing a larger number of patients were included in this study. The larger sample size increased the reliability of our results. In addition, this meta-analysis was conducted on a basis of good quality studies. Although publication bias existed among our included studies, the results of trim and fill method and a sensitivity analysis also confirmed that the pool results had no significant changes. Despite these, our results should be considered in light of limitations. First, a high heterogeneity existed in this study. One possibility for this was that the sample size differed among different studies, which may result in inconsistent $95 \%$ CI. Second, among all included studies, 13 were cohort studies and one was a RCT study. Third, we did not collect baseline nutritional data on the cohorts, especially the data on folic acid intake from food. In consideration of the findings of Ray and Mamdani [40] that folic acid from food intake was very low to make any impact on the risk of preeclampsia, we believe that supplementation of multivitamins containing folic acid during pregnancy may be beneficial. Fourth, the dosage of folic acid is largely unknown due to lack of related information in included studies and the period in which the women received folic acid was insistent, which may influence the effects of folic acid on the prevention of preeclampsia. Notably, previous findings showed that there was no significant association between dosage of folic acid supplementation and the strength of its effect [41, 42], but an inverse relationship exists between the duration of folic acid supplementation and the risk of stroke [42], suggesting that the supplementation duration of folic acid is more important than its dosage. A further analysis on exploring key period of folic acid supplementation may have important clinical significance. Considering the different study design among studies, our results are still needed to be further verified by more high-quality clinical studies.

In conclusion, the findings of this meta-analysis indicate that the supplementation of multivitamins containing folic acid during pregnancy may reduce preeclampsia risk. Multivitamin supplementation may be considered as a promising prevention strategy for preeclampsia.

Author contributions CL: made the inclusion criteria and exclusion criteria, explored the literature, document selection, data extraction, data analysis, and composed the manuscript. CL: made the inclusion criteria and exclusion criteria, document selection, data analysis. QW: explored the literature, document selection, data extraction. ZZ: posed a question, made the inclusion criteria and exclusion criteria, and composed the manuscript

Funding This study was funded by the International Cooperation Project with Russia (Grant Number 2015DFR31070) and Beijing Municipal Administration of Hospitals Clinical Medicine Development of Special Funding Support (Grant Number ZYLX201713). 


\section{Compliance with ethical standards}

Conflict of interest The authors declare that they have no conflict of interest.

Ethical approval This article does not contain any studies with human participants performed by any of the authors.

Open Access This article is distributed under the terms of the Creative Commons Attribution 4.0 International License (http://creativeco mmons.org/licenses/by/4.0/), which permits unrestricted use, distribution, and reproduction in any medium, provided you give appropriate credit to the original author(s) and the source, provide a link to the Creative Commons license, and indicate if changes were made.

\section{References}

1. Ayansina D, Black C, Hall S, Marks A, Millar C, Prescott G, Wilde K, Bhattacharya S (2016) Long term effects of gestational hypertension and pre-eclampsia on kidney function: record linkage study. Pregnancy Hypertens 6(4):344-349

2. Masoudian P, Nasr A, de Nanassy J, Fung-Kee-Fung K, Bainbridge SA, El Demellawy D (2016) Oocyte donation pregnancies and the risk of preeclampsia or gestational hypertension: a systematic review and metaanalysis. Am J Obstet Gynecol 214(3):328-339

3. McGinnis R, Steinthorsdottir V, Williams NO, Thorleifsson G, Shooter S, Hjartardottir S, Bumpstead S, Stefansdottir L, Hildyard L, Sigurdsson JK (2017) Variants in the fetal genome near FLT1 are associated with risk of preeclampsia. Nat Genet 49(8):1255-1260

4. Al-Jameil N, Khan FA, Khan MF, Tabassum H (2014) A brief overview of preeclampsia. J Clin Med Res 6(1):1

5. Nomura Y, John RM, Janssen AB, Davey C, Finik J, Buthmann J, Glover V, Lambertini L (2017) Neurodevelopmental consequences in offspring of mothers with preeclampsia during pregnancy: underlying biological mechanism via imprinting genes. Arch Gynecol Obstet 295(6):1319-1329

6. Garovic VD, Bailey KR, Boerwinkle E, Hunt SC, Weder AB, Curb D, Mosley TH Jr, Wiste HJ, Turner ST (2010) Hypertension in pregnancy as a risk factor for cardiovascular disease later in life. J Hypertens 28(4):826

7. Magnussen EB, Vatten LJ, Smith GD, Romundstad PR (2009) Hypertensive disorders in pregnancy and subsequently measured cardiovascular risk factors. Obstet Gynecol 114(5):961-970

8. Roberts JM, Pearson G, Cutler J, Lindheimer M (2003) Summary of the NHLBI working group on research on hypertension during pregnancy. Hypertension 41(3):437-445

9. Sanchez SE, Zhang C, Rene Malinow M, Ware-Jauregui S, Larrabure G, Williams MA (2001) Plasma folate, vitamin B12, and homocyst(e)ine concentrations in preeclamptic and normotensive Peruvian women. Am J Epidemiol 153(5):474-480

10. Vollset SE, Refsum H, Irgens LM, Emblem BM, Tverdal A, Gjessing HK, Monsen ALB, Ueland PM (2000) Plasma total homocysteine, pregnancy complications, and adverse pregnancy outcomes: the Hordaland Homocysteine study. Am J Clin Nutr 71(4):962-968

11. Sudchada P, Saokaew S, Sridetch S, Incampa S, Jaiyen S, Khaithong W (2012) Effect of folic acid supplementation on plasma total homocysteine levels and glycemic control in patients with type 2 diabetes: a systematic review and meta-analysis. Diabetes Res Clin Pract 98(1):151-158
12. Rumbak I, Žižic V, Vrkic N, Baric IC (2015) Folic acid supplementation impact on homocysteine and C-terminal crosslinking telopeptides of type I Collagen. Eur J Nutr Food Saf 5(5):1157-1158

13. Vanderlelie J, Scott R, Shibl R, Lewkowicz J, Perkins A, Scuffham PA (2016) First trimester multivitamin/mineral use is associated with reduced risk of pre-eclampsia among overweight and obese women. Matern Child Nutr 12(2):339-348

14. Wen SW, Guo Y, Rodger M, White RR, Yang Q, Smith GN, Perkins SL, Walker MC (2016) Folic acid supplementation in pregnancy and the risk of pre-eclampsia-a cohort study. PLoS One 11(2):e0149818

15. Wang Y, Zhao N, Qiu J, He X, Zhou M, Cui H, Lv L, Lin X, Zhang C, Zhang H, Xu R, Zhu D, Dang Y, Han X, Zhang H, Bai H, Chen Y, Tang Z, Lin R, Yao T, Su J, Xu X, Liu X, Wang W, Ma B, Liu S, Qiu W, Huang H, Liang J, Wang S, Ehrenkranz RA, Kim C, Liu Q, Zhang Y (2015) Folic acid supplementation and dietary folate intake, and risk of preeclampsia. Eur J Clin Nutr 69(10):1145-1150. https://doi.org/10.1038/ejcn.2014.295

16. Li Z, Ye R, Zhang L, Li H, Liu J, Ren A (2013) Folic acid supplementation during early pregnancy and the risk of gestational hypertension and preeclampsia. Hypertension 61(4):873

17. Higgins JP, Green S (2010) Cochrane Handbook for Systematic Reviews of Interventions. Naunyn-Schmiedebergs Archiv für experimentelle Pathologie und Pharmakologie 5(2):S38

18. Wells G, Shea B, O'connell D, Peterson J, Welch V, Losos M, Tugwell P (2000) The Newcastle-Ottawa Scale (NOS) for assessing the quality of nonrandomised studies in meta-analyses

19. Higgins JP, Thompson SG, Deeks JJ, Altman DG (2003) Measuring inconsistency in meta-analyses. BMJ 327(7414):557-560. https://doi.org/10.1136/bmj.327.7414.557

20. Feng RN, Zhao C, Sun CH, Li Y (2011) Meta-analysis of TNF $308 \mathrm{G} / \mathrm{A}$ polymorphism and type 2 diabetes mellitus. PLoS One 6(4):e18480. https://doi.org/10.1371/journal.pone.0018480

21. Bodnar LM, Tang G, Ness RB, Harger G, Roberts JM (2006) Periconceptional multivitamin use reduces the risk of preeclampsia. Am J Epidemiol 164(5):470-477. https://doi.org/10.1093/aje/ kwj218

22. Bukowski R, Malone FD, Porter FT, Nyberg DA, Comstock CH, Hankins GDV, Eddleman K, Gross SJ, Dugoff L, Craigo SD (2009) Preconceptional folate supplementation and the risk of spontaneous preterm birth: a cohort study. PLoS Med 6(5):e1000061

23. Catov JM, Bodnar LM, Olsen J, Olsen S, Nohr EA (2011) Periconceptional multivitamin use and risk of preterm or small-forgestational-age births in the Danish National Birth Cohort. Am J Clin Nutr 94(3):906-912

24. Charles DHM, Ness AR, Campbell D, Smith GD, Whitley E, Hall MH (2005) Folic acid supplements in pregnancy and birth outcome: re-analysis of a large randomised controlled trial and update of Cochrane review. Paediatr Perinat Epidemiol 19(2):112-124

25. Hernandez-Diaz S, Werler MM, Louik C, Mitchell AA (2002) Risk of gestational hypertension in relation to folic acid supplementation during pregnancy. Am J Epidemiol 156(9):806-812

26. Kim MW, Ahn KH, Ryu KJ, Hong SC, Lee JS, Nava-Ocampo AA, Oh MJ, Kim HJ (2014) Preventive effects of folic acid supplementation on adverse maternal and fetal outcomes. PLoS One. https://doi.org/10.1371/journal.pone.0097273

27. Liu X, Lv L, Zhang H, Zhao N, Qiu J, He X, Zhou M, Xu X, Cui H, Liu S, Lerro C, Lin X, Zhang C, Zhang H, Xu R, Zhu D, Dang Y, Han X, Bai H, Chen Y, Tang Z, Lin R, Yao T, Su J, Wang W, Wang Y, Ma B, Huang H, Liang J, Qiu W, Liu Q, Zhang Y (2016) Folic acid supplementation, dietary folate intake and risk of preterm birth in China. Eur J Nutr 55(4):1411-1422. https:// doi.org/10.1007/s00394-015-0959-1 
28. Martinussen MP, Bracken MB, Triche EW, Jacobsen GW, Risnes KR (2015) Folic acid supplementation in early pregnancy and the risk of preeclampsia, small for gestational age offspring and preterm delivery. Eur J Obstet Gynecol Reprod Biol 195:94-99. https://doi.org/10.1016/j.ejogrb.2015.09.022

29. Timmermans S, Jaddoe VW, Silva LM, Hofman A, Raat H, Steegers-Theunissen RP, Steegers EA (2011) Folic acid is positively associated with uteroplacental vascular resistance: the generation R study. Nutr Metab Cardiovasc Dis 21(1):54-61. https:// doi.org/10.1016/j.numecd.2009.07.002

30. Wen SW, Chen XK, Rodger M, Rennicks White R, Yang Q, Smith GN, Sigal RJ, Perkins SL, Walker MC (2008) Folic acid supplementation in early second trimester and the risk of preeclampsia. Am J Obstet Gynecol 198(1):41-45. https://doi.org/10.1016/j. ajog.2007.06.067

31. Li Z, Ye R, Zhang L, Li H, Liu J, Ren A (2013) Folic acid supplementation during early pregnancy and the risk of gestational hypertension and preeclampsia. Hypertension 61(4):873-879. https://doi.org/10.1161/HYPERTENSIONAHA.111.00230

32. Duval S, Tweedie R (2000) Trim and fill: a simple funnel-plotbased method of testing and adjusting for publication bias in metaanalysis. Biometrics 56(2):455-463

33. Roberts JM, Cooper DW (2001) Pathogenesis and genetics of preeclampsia. Lancet 357(9249):53-56

34. Steegers-Theunissen RPM, Smith SC, Steegers EAP, Guilbert LJ, Baker PN (2000) Folate affects apoptosis in human trophoblastic cells. BJOG 107(12):1513-1515
35. Di SN, Riccardi P, Maggiano N, Piacentani A, D'Asta M, Capelli A, Caruso A (2004) Effect of folic acid on homocysteine-induced trophoblast apoptosis. Mol Hum Reprod 10(9):665-669

36. Catov JM, Nohr EA, Bodnar LM, Knudson VK, Olsen SF, Olsen J (2009) Association of periconceptional multivitamin use with reduced risk of preeclampsia among normal-weight women in the Danish National Birth Cohort. Am J Epidemiol 169(11):1304-1311

37. Poston L, Briley A, Seed P, Kelly F, Shennan A, Consortium ViPeT (2006) Vitamin C and vitamin E in pregnant women at risk for pre-eclampsia (VIP trial): randomised placebo-controlled trial. Lancet 367(9517):1145-1154

38. Rumbold AR, Crowther CA, Haslam RR, Dekker GA, Robinson JS (2006) Vitamins C and E and the risks of preeclampsia and perinatal complications. N Engl J Med 354(17):1796-1806

39. Lv SS, Wang JY, Wang XQ, Wang Y, Xu Y (2016) Serum vitamin D status and in vitro fertilization outcomes: a systematic review and meta-analysis. Arch Gynecol Obstet 293(6):1339-1345

40. Ray JG, Mamdani MM (2002) Association between folic acid food fortification and hypertension or preeclampsia in pregnancy. Arch Intern Med 162(15):1776-1777

41. Lumley J, Watson L, Watson M, Bower C (2001) Periconceptional supplementation with folate and/or multivitamins for preventing neural tube defects. Cochrane Database Syst Rev 3:CD001056

42. Wang X, Qin X, Demirtas H, Li J, Mao G, Huo Y, Sun N, Liu L, Xu X (2007) Efficacy of folic acid supplementation in stroke prevention: a meta-analysis. Lancet 369(9576):1876-1882 